Research Article

Araştırma Makalesi

DOI: $10.24011 /$ barofd.785895
Bartın Orman Fakultesi Dergisi,

23 (1): 18-35,

15 Nisan/April, 2021
Journal of Bartin Faculty of Forestry

p-ISSN :1302-0943

e-ISSN :1308-5875

\title{
Sürdürülebilir Kentsel Açık-Yeşil Alanlar Olarak Mezarlıklar Ve Sunduğu Ekosistem Hizmetleri: Tarihi Seyyid Burhaneddin Mezarlığı- Kayseri
}

\author{
Aslıhan TIRNAKÇI ${ }^{1 *}$ \\ ${ }^{1}$ Nevşehir Hacı Bektaş Veli Üniversitesi, Mühendislik-Mimarlık Fakültesi, Peyzaj Mimarlığı Bölümü,50300, \\ NEVŞEHIR
}

Öz

Hızla artan kentleşme ile birlikte kentsel alanlardaki açık-yeşil alanlar giderek azalmaktadır. Kültürel tarihin önemli bir parçası olan mezarlıklar kentsel açık-yeşil alan sistemlerinin önemli bir parçasını oluşturmaktadır. Dolayısıyla mezarlıklar sahip oldukları yeşil doku ile kentsel alanlarda giderek önemi artan geniş açık-yeşil alanlardandır. Kentsel açık-yeşil alanlar, kentsel biyolojik çeşitliliği destekleme, kent iklimini iyileştirme, kent estetiğine katkı sağlama gibi birçok ekosistem hizmeti sağlamaktadır.

$\mathrm{Bu}$ çalışmada, Kayseri kentinde yer alan ve Kayseri kültürel tarihinin önemli bir parçası olan Tarihi Seyyid Burhaneddin Mezarlığı'nın kentsel açık-yeşil alan sistemi içerisindeki önemi ve yeniden kentsel peyzaja kazandırılması irdelenmiştir. Daha sonra kente ve kentsel yaşama kazandırdığı kültürel ve düzenleyici ekosistem servisleri belirlenen parametreler çerçevesinde incelenmiş, çalışma alanının sağladığı ekosistem hizmetleri ortaya konmuştur.

Anahtar Kelimeler: Mezarlıklar, ekosistem hizmetleri, kentsel açık-yeşil alan, Seyyid Burhaneddin Mezarlı̆̆ı (Kayseri).

\section{Cemeteries As Sustainable Urban Open-Green Areas And Ecological Services Offered: Historical Seyyid Burhaneddin Cemetery-Kayseri}

\begin{abstract}
Open-green areas in urban areas are gradually decreasing with the rapidly increasing urbanization. Being an important part of cultural history, cemeteries are an important part of urban open-green space systems. Therefore with their green texture cemeteries are becoming increasingly significant wide open-green areas. Urban open-green spaces provide many ecosystem services such as supporting urban biodiversity, improving the urban climate and contributing to the urban aesthetics.

In this study, the Historical Seyyid Burhaneddin Cemetery, which is located in the city of Kayseri and is an important part of the cultural history of Kayseri, was examined its importance in the urban open-green area system and its refunction to the urban landscape. Then, the cultural and regulating ecosystem services that it brings to the city and urban life were examined, and the ecosystem services provided by the study area were revealed within the framework of the determined parameters.
\end{abstract}

Keywords: Cemeteries, ecosystem services, urban open-green areas, Seyid Burhaneddin Cemetery (Kayseri)

\footnotetext{
*Sorumlu Yazar (Corresponding Author):

Aslıhan TIRNAKÇI ((Dr. Öğr. Üyesi),NHBV Üniversitesi Mühendislik-Mimarlık 


\section{Giriş}

Kentler, arazi kullanımının en yoğun, insan etkisinin en fazla olduğu mekânlardır (Korkut vd., 2017). Son yıllarda artan kentsel nüfusla birlikte yapısal çevrenin doğa üzerindeki baskısı artmış beraberinde iklim değişikliği, kentsel 1S1 adası, biyoçeşitliliğin azalması gibi ekolojik birçok çevre sorunu ortaya çıkmıştır. Bu sorunların oluşturduğu çevresel baskı ile "yaşanabilirlik" ve "sürdürülebilirlik" gibi kavramların sorgulandığı bir kentsel tasarım sürecine girilmiştir (Lynch, 1985). Bu süreçte, kentte akciğer görevi gören kentsel açık-yeşil alanların varlığı önem kazanmıştır (Bulut vd., 2010).

Kentsel açık-yeşil alanlar sürdürülebilir kentsel gelişim sürecinde oldukça etkilidir. Kent içinde veya yakın çevresinde bulunan yeşil alan dokuları, kendi içinde bir ekolojik sistem oluşturarak doğal alan ve yapısal çevre arasında dengeli bir arazi kullanımı sağlamakta, büyüyen kentlerde sağlıklı bir kentsel gelişim sürecini desteklemektedir (Eminağaoğlu ve Yavuz 2010).

Kentsel yeşil alanlar, giderek kentleşen toplumumuzun yaşam kalitesi için (Girardet, 1992; EEA, 1995, 1998) ve insan-doğa arasındaki bozulan ilişkiyi dengelemede ( Gül ve Küçük, 2001) stratejik bir öneme sahip arazi kullanım şeklidir. Açık-yeşil alanlar pek çok farklı işlev üstlenmekte ve bu işlevler ölçüsünde önem kazanmaktadırlar. Kentsel yaşamda açık-yeşil alanlar; kentlinin uzun vadeli ruhsal ve fiziksel iyileşmesini sağlamaktan (Velarde et. al., 2007; Qin et al.., 2013) kentsel biyoçeşitliliğin korunmasına ve geliştirilmesine (Kattwinkel et al., 2011), oksijen üretiminden (Jo, 2002; La Rosa, 2014) 1s1 adalarını ve yüzey akış1 azaltmaya, hava kalitesini düzenlemeye (Bowler et al., 2010; Depietri et al., 2012; Manes et al., 2012; Sander and Zhao, 2015), gürültü kirliliğini azaltmaya (Pathak et al., 2011), turizmin gelişmesinden konut alanları ile ticaret ve sanayi alanları arasında tampon bölgeler oluşturmaya, yaya ve taşıt dolaşımını kolaylaştırmaya varıncaya kadar pek çok işlev üstlenmiştir. Bu işlevler kentsel yaşamda fiziksel, estetik, toplumsal, psikolojik, ekonomik ve ekolojik işlevler olarak ortaya çıkmaktadırlar (Öztan, 1974).

Gündüz (1989) kentsel açık-yeşil alanları;

- Mutlak işleve sahip alanlar (yollar, hava alanları, mezarlıklar, tarım alanları, otoparklar)

- Estetik ve rekreasyon amaçlı kullanılan ve kendi içerisinde özel yeşil alanlar (golf alanları, ev bahçeleri)

- Sosyal yeşil alanlar (topluma yarı açık; resmi kuruluşlar, tarihi, dini yapılar, hastaneler, okul bahçeleri, özel spor kulüplerine ait alanlar ve topluma açık alanlar; parklar, bakış noktaları, pasif alanlar, görsel yeşillikler, refüjler, meydanlar, dekoratif yeşillikler, bulvarlar, çocuk bahçeleri, çocuk oyun alanları, yüzme tesisleri, spor alanları) şeklinde sınıflandırmıştır (Özdemir, 2012).

Kentsel alanlarda kenti tek bir ekosistem olarak tanımlamak ya da kentin birkaç ekosistemden oluştuğunu görmek mümkündür (Rebele, 1994; Bolund and Hunhammar, 1999). Kentlerde sokak ağaçlarından göletlere kadar kentte bulunan bütün yeşil ve mavi alanlar kentsel ekosistemin bir parçasıdır (Rebele, 1994). Bu bağlamda kentsel açıkyeşil alanlar (ör: kent parkları, mezarlıklar) kentsel ekosistemin önemli bir parçasıdır ve bu alanlar farklı ekosistem hizmetleri sunmaktadır (Karaşah, 2018).

Ekosistem hizmetleri, insan yaşamını ve refahını sürdürmek için ekosistemler tarafından sunulan tüm durumlar, süreçler, işlevler, yardımcı programlar ve ürünler olarak tanımlanabilir (Albayrak, 2012). Ekosistem hizmetleri tedarikçi, düzenleyici, kültürel ve destekleyici olmak üzere dört başlık altında sınıflandırılmıştır (Millennium Ecosystem Assessment (MEA), 2005). Kentsel ekosistemler; hava kalitesini düzenleme, iklim düzenleme, su kalitesini düzenleme, kültürel miras değeri, rekreasyon ve eğitim değeri gibi ekosistem servisleri sağlamaktadır (Anonymous, 2005).

\subsection{Mezar ve Mezarlık Kavramı}

Mezar kelime anlamı olarak ölülerin gömüldüğü yer anlamını taşımaktadır. Mezarlık ise yaşam fonksiyonlarını tamamı ile yitirmiş organ ve kadavraların toprak içinde mikroorganizmalarca parçalanacağı, çevre sağlığına zarar vermeyecek şekilde uygun derinlikte, yasal ve dini kurallara uygun şekilde ölünün defin yerini belirten, üzeri kapatılmış çözülme odalarının toplu şekilde bulunduğu yerlerdir (Türkal, 1980; Uslu,1997). Mezarlıklar toplumların inançları ve kültürlerini yansıtan mekânlardır. Örneğin, mezarlık İngilizcede uyku mekânı, Almancada huzur yeri, Osmanlıcada ise ziyaret yeri olarak tanımlanmaktadır (Aktan, 1999; Uslu, 1997). Mezar yapılarının biçimlenmesi ölümden sonra yaşamın sürdüğü inancına dayanmaktadır (Uslu, 1997). Bu inançla birlikte mezarlık geleneği belirlenmiş ve bunun sonucu binlerce yıl ayakta kalabilen yapılar ortaya çıkmıştır (Şekil 1). Dolayısıyla insanlar gelecek kuşaklara varlıklarını ispat edebilmek için sosyal ve ekonomik durumlarına göre öldükten sonrada hatırlanabilecekleri irili ufaklı, gösterişli, gösterişsiz yapılardan oluşan mezarlıklar bırakmışlardır (Gönen, 1992). 




Şekil 1. Farklı inanışlara göre biçimlenmiş anıt mezarlar (a: Giza Piramitleri (Anonim, 2020a); b:Tac Mahal (Anonim, 2020b))

\section{2. İslam Öncesi ve Sonrası Türk Kültüründe Mezar ve Mezarlıklar}

İslam öncesi Türk uygarlıkları mezarlık kültürlerinde Şaman, Upaniş, Budist ve Hindu doktrinlerinden etkilenmiştir (Özarslan, 2007). Dolayısıyla Türklerde mezar ve mezarlık geleneği, dönemsel ve kültürel farklılıkların etkisinde kalmıştır. Orta Asya Türkleri ölülerini ya yaktıktan veya mumyaladıktan sonra ya da doğrudan gömerlerdi. Gömme tekniği Çin etkisinden doğmuş, yakıldıktan sonra gömme işlemi ise Hint kültürü ile Budizim dininden ortaya çıkmıştır. Bu yöntemlerin dışında nadir örnek olmakla birlikte ölülerini parçalamak üzere kartal gibi vahşi hayvanlara bırakan Türk kavimlerine de rastlanır (Saraçoğlu, 1950). Türkler tarafından kullanılan ilk mezar yapısı anıt mezar niteliğindeki "Kurgan"dır. Ölen kişi asil ise "kurgan" adı verilen anıt mezara genellikle mumyalanarak, asil değil ise "babal" adı verilen taş parçalarının başucuna dikildikleri basit mezara gömülürdü (Başkan, 1996) (Şekil 2).
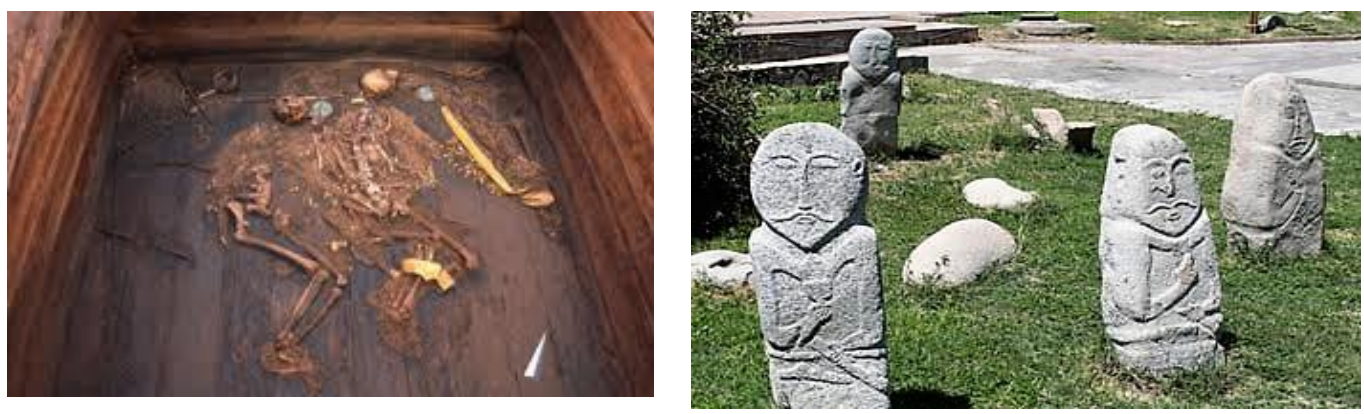

Şekil 2. Kurgan mezar ve Babal taşları örneği (Anonim 2020d, Anonim 2020e)

Şamanizm dinini benimseyen Hunlar ruhun ölmediği inancıyla ölüyü eşya ve hediyeleri ile birlikte gömer, ruhun rahat etmesi inancı ile de mezar odasını ipek ve yün keçelerle donatırlardı (Uslu, 1997). Yine Şamanizm etkisiyle Göktürklerde ölülerini eşyaları ile birlikte gömmüşlerdir. Ayrıca ölenin sosyal statüsüne göre farklı boyutlarda mezar taşları kullanmışlardır (Tuncel, 1989). Budizm'i kabul eden Uygurlar ise, ölülerini Göktürklerdeki gibi taşhöyük denen büyük yuvarlak tepe şeklinde yerlere gömmüşlerdir (Saraçoğlu, 1950). Daha sonra Uygurlar Anadolu'da çokça görülen türbe ve kümbet mimarisinin temelini oluşturan, üzeri kubbe gibi örtülen ve "stuba" adı verilen mezarlar yapmışlardır (Tuncel, 1989).

Din mezar geleneğinde en etkili öğedir. Türklerin İslam dinini kabul etmeleriyle, mezar-mezarlık geleneği yeni tiplerle devam etmiş (Uslu, 1997; Özkardaş, 2010), yalnız toprağa gömülme (tabutsuz) tarzını benimsemişlerdir (Bekiroğlu, 1990; Özarslan, 2007). İslamiyet ile birlikte mezarlar kıbleye (güneye) doğru yönelmiş, mezar taş1 dikme geleneği de devam etmiştir. Devlet adamı ve kutsal kişilere ait mezarların simgeleştirilmesi ilk kez Karahanlılar'da “türbe" veya "kümbet” adı verilen mezar anıtlarıyla başlamıştır (Tuncel, 1989). Bu mezar yapıları eski Türk mezar çadırları kalıntılarıdır (Daneshvari, 1986), ve türbeler Türk çadırlarının taş yorumlamasıdır (Akurgal, 1990). Dolayısıyla İslam öncesi kavramlar farklı yorumlamalarla varlığını sürdürmüştür (Tuncer, 1996) (Şekil, 3). 


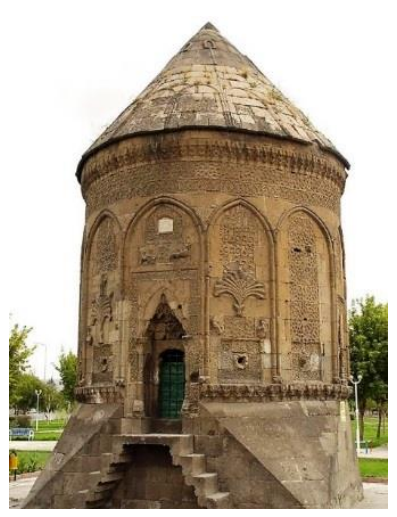

a

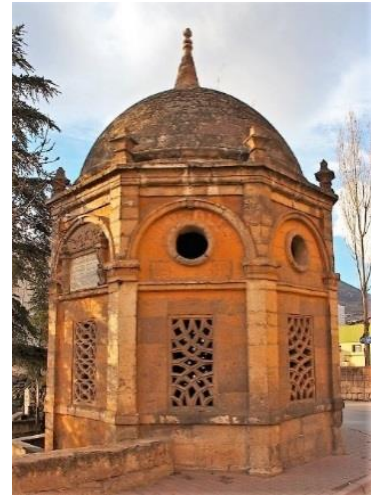

b

Şekil 3. Anadolu Selçuklu Mezar Örnekleri (a: Döner Kümbet (Anonim, 2020f); b: Esma Sultan Türbesi (Anonim, 2020g), Kayseri)

\subsection{Türk Kültüründe Kentsel Yeşil Alan Sistemi İçerisinde Mezarlıklar}

Eski Türk kentleri onları meydana getiren camiler, medreseler, hanlar, hamamlar, çeşmeler, konaklar, geleneksel evlerle birlikte kendisini çevreleyen mezarlıklarla birlikte kimliğini ortaya koymuştur (Eyice, 1996). Türkler hem mezarlarını kötü ruhlardan korumak için (Saraçoğlu, 1950) hem de doğaya olan hayranlıklarının bir göstergesi olarak için ölülerini hep yüksek yerlere gömmüşler, mezarlıkların manzarası güzel tepe ve yamaçlara kurarak orman ya da koru haline getirerek gizlemişlerdir (Güneş, 1995). Türk mezarlıkları, ulu ve görkemli ağaçların gölgelediği bir koruluk, doğal bir bahçe olarak kentsel açık-yeşil alan sistemleri içinde önemli yere sahip alanlar olmuşlardır (Eyice, 1996).

Osmanlı kentlerinde mezarlıklar, daima güzel manzaraya sahip alanlarda kurulmuş ve yerleşim alanları içinde ziyaret, dinlenme ve meditasyon yeri olarak hizmet sunan bir kent parkı niteliğinde alanlar olmuştur (Karaoğlu, 2007). Mezarlık alanlar yeşillikler arasında adeta kaybolmuş, yeşilin ve taşların ahengiyle adeta bütünleşmiş biçimdedir (Aktan, 1999).

Mezarlıklar farklı kültürlerin ve dinlerin etkisinde her ne kadar ölülerin mekânı olarak tanımlansa da aslında yaşayan mekânlardır (Uslu, 2010). Bu bağlamda mezarlıklar yerleşimle iç içe kuruldukları için, yaşayanların yeşil dokusundan ve manzarasından yararlandıkları, dinlendikleri, hemen hemen günümüz parklarının insanlara sağladı̆̆ı bir takım fonksiyonları içeren yeşil alanlar olarak her dönemde Türk kentlerinin yapısında önemli rol oynamışlardır (Gönen, 1992; Karaoğlu, 2007). Ancak günümüzde mezarlıkların durumu Osmanlı dönemindekinden çok farklı olup, günlük yaşamın içinde, etrafı açık ve huzur dolu mekânlar olmaktan çıkmış insana korku ve ürperti veren mekânlar olarak şehirlerin dışına itilmiştir (Taner, 1988). Türkler'in Anadolu'ya yerleştikten sonraki dönemlere ait tespit edilen mezarlıkların çok azı günümüze kadar kalabilmiştir. Tarihi kent mezarlıkları önemli bir kültür ve kültürel miras taşıyıcılarıdır (Sommer, 2003; Worpole, 2003). Evensen et al. (2017)'ye göre kent mezarlıkları, mezar ziyaretlerinin ötesinde çok çeşitli rekreasyonel etkinlikler için kullanılabilen ve bu nedenle çok işlevli bir açık-yeşil alan niteliğine sahip kentsel alanlardır. Ayrıca kent ve yakın çevresindeki bu alanlar kentin açık yeşil alanlarını birbirine bağlayan organik bağları da oluşturmaktadır (Güçlü vd., 1996)

$\mathrm{Bu}$ çalışmada, Kayseri Kentinin önemli tarihi mezarlıklarından biri olan Seyyid Burhaneddin Mezarlı̆̆ bir kültürel peyzaj bileşeni olarak ele alınmış, çalışma alanının sunduğu ekosistem hizmetleri incelenmiştir. Kentsel mezarlık alanlar; destekleyici ve tedarik edici ekosistem hizmetleri sağlama potansiyeline sahiptir (Clayden et al., 2018). Ancak bu çalışmada mezarlık alanlarının sunduğu düzenleyici ve kültürel ekosistem hizmetlerine odaklanılmıştır.

\section{Materyal ve Metot}

\subsection{Materyal}

Çalışmanın ana materyalini Tarihi Seyyid Burhaneddin Mezarlığı oluşturmaktadır. Kayseri ili, Melikgazi ilçesi, Hunat mahallesinde yer alan mezarlığın güneyinde önemli bulvarlardan biri olan Seyyid Burhaneddin Bulvarı (Talas Bulvarı), kuzeyinde önemli açık-yeşil alanlardan biri olan Gültepe Parkı bulunmaktadır (Şekil 4). 


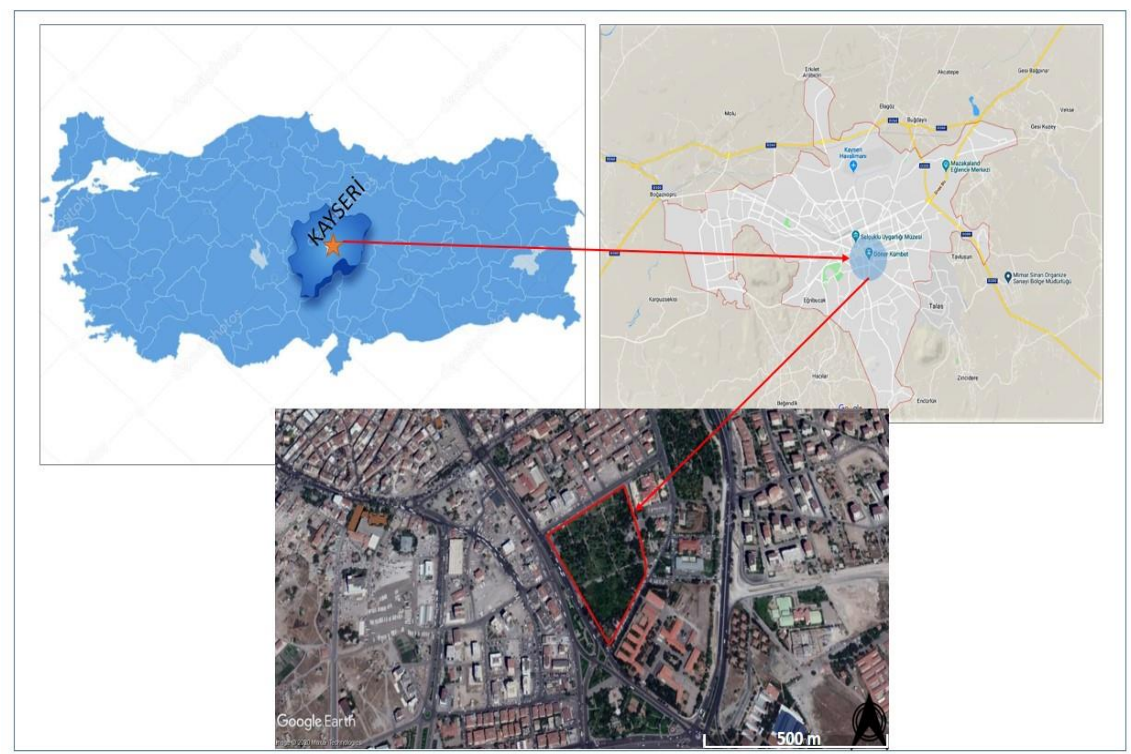

Şekil 4. Çalışma alanı coğrafi konumu (Google Earth)

Seyyid Burhaneddin Mezarlığı Anadolu'nun en eski şehirlerinden biri olan Kayseri'de günümüze kadar ulaşmış tarihi mezarlardan biridir. Çalışma alanı 13. yy'dan beri içerisine gömü yapılan, bir mezarlık alanı olarak; Anadolu'nun da en eski mezarlıklarından biri olarak önemli bir yere sahiptir (Sağıroğlu Arslan, 2018). Çalışma alanı sınırlarını Seyyid Burhaneddin Hz. Türbesi (1893) ve Emir Erdoğmuş Türbesi'nin (15. yy) etrafındaki 6 ha alan büyüklüğündeki mezarlık alanı oluşturmaktadır. Mezarlıkta Anadolu Selçuklu, Beylikler, Osmanlı ve Cumhuriyet Dönemi olmak üzere farklı dönemlere ait mezarlar bulunmaktadır. Kayseri Asri Mezarlığı'nın yapılması ile 1955 yılından sonra mezarlığa gömü yapılması yasaklanmıştır (Anonim, 1991). Kayseri Büyükşehir Belediyesi tarafından 2003 ve 2007 yıllarında yapılan çevre düzenleme çalışması ile mezarlık alanındaki mevcut ağaçlar korunarak bakım onarım çalışmaları yapılmıştır. Ayrıca alanda çim alan tesisi yapılarak açık-yeşil alan olarak kentsel peyzaja kazandırılmıştır (Şekil 5).

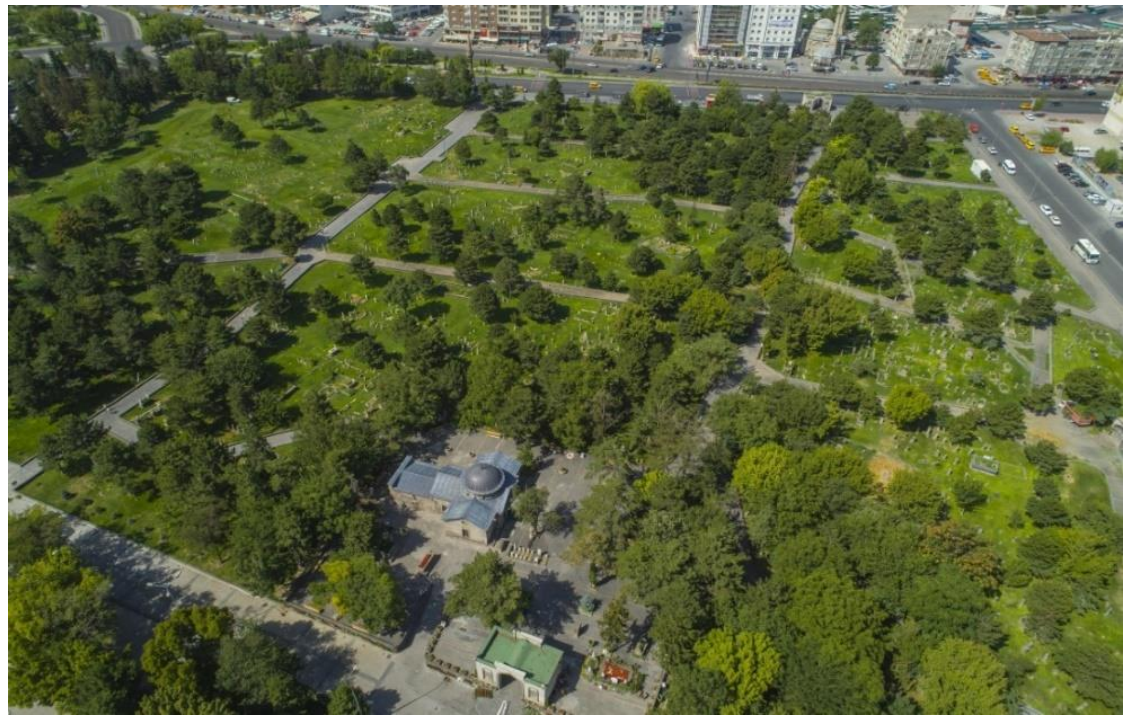

Şekil 5. Seyyid Burhaneddin Mezarlığı genel görünümü (Anonim, 2020h)

\subsection{Seyyid Burhaneddin Mezarlığının Tarihsel Gelişimi}

Seyyid Burhaneddin Mezarlığı Anadolu Selçuklu döneminden günümüze asli halini, büyük oranda koruyarak, ulaşabilmiş kentin en eski mezarlığıdır. Mezarlığın bugün kapladığı alan, eski mezarlık alanından daha azdır. Ali Cafer Kümbeti ile başlayan, Seyyid Burhaneddin Mezarlığı ile devam eden, Hava Şehitliği'ni de içine alarak, Döner Kümbet ve Emir Ali Kümbeti ile Kartal Bölgesi'nde sonlanan bu alan; türbelerden ve mezarlıktan oluşan önemli bir mezarlık bölgesidir (Şekil 6). Alan mezarlık vasfını Osmanlı ve Cumhuriyet Dönemlerinde de içerisine defin yapılmasıyla devam ettirmiştir (Sağıroğlu Arslan, 2018). 


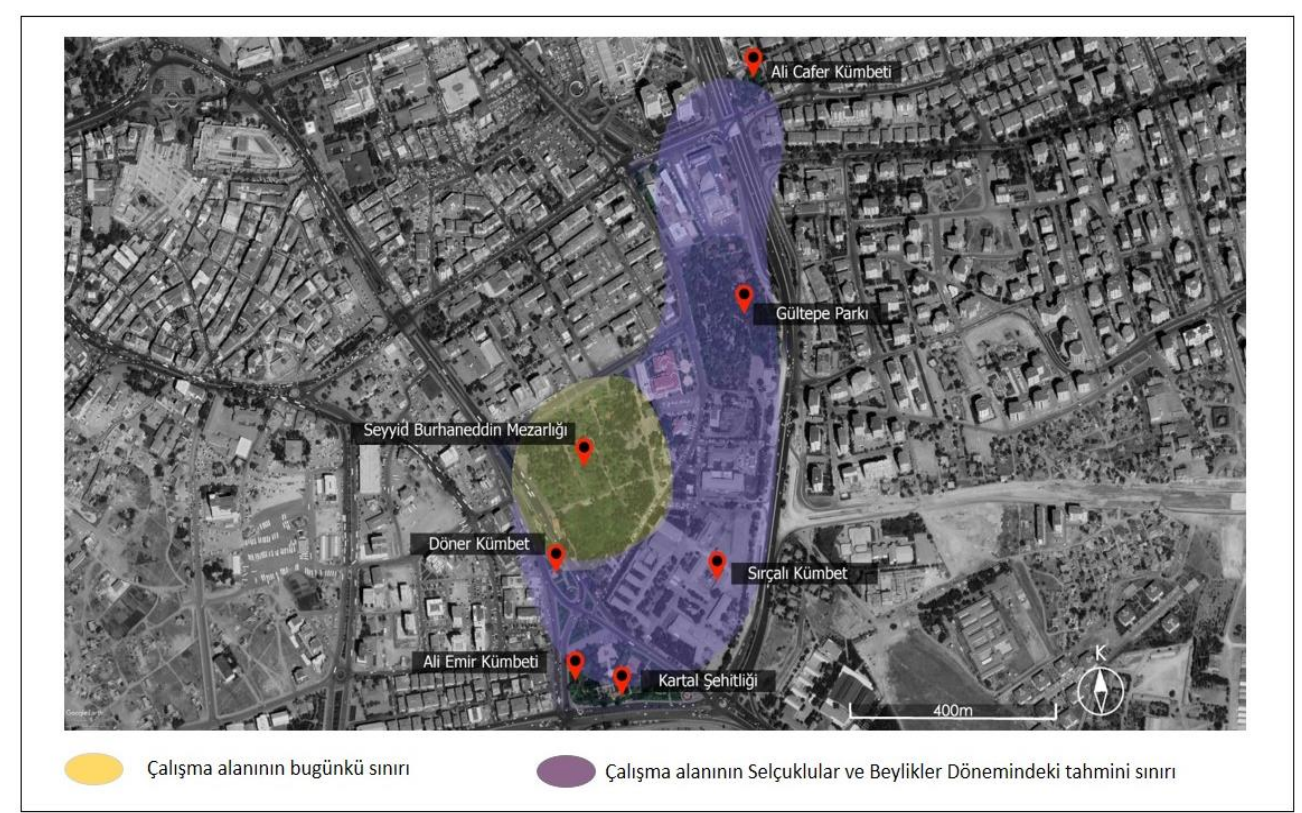

Şekil 6. Seyyid Burhaneddin Mezarlığının kapladığı alan sınırının değişimi (Literatüre dayalı tahmini olarak oluşturulmuştur)

Kayseri'de yaşamış bütün tanınmış kişilerin defnedildiği bölgeye, Seyyid Burhaneddin Veli’nin mezarı bu bölgede olduğu için zamanla Seyyid Burhaneddin mezarlığı denmiştir (Hüsrevoğlu, 2017). Mezarlığın kuzeyinde bulunan Gültepe Parkı 1900'lü yıllarda planlanmış, 1910'da hizmete açılmıştır. Park olarak tasarlanan bu alan mezarlık alanının bir kısmının ortadan kalkmasına sebep olmuștur (İmamoğlu, 1997). Bakımsız ve harabe görünümündeki türbe ve mezarlık alanının bakımı ve onarılması için 1965 yılında bir dernek kurulmuştur. $\mathrm{Bu}$ dernek mezarlı̆ğ duvarlarla çevirmiş, içerisine su getirtmiş ve ağaçlandırmıştır (Satoğlu, 1968). 1957 yılında Kayseri Belediyesi tarafindan Talas Caddesi'nin (Seyyid Burhaneddin Bulvarı) iki tarafindaki evler istimlak edilerek bu yol bulvara dönüştürmüştür. Bu esnada Seyyid Burhaneddin Mezarlığı'nın bir kısmını da yola katmıştır (Çalışkan, 1995). Kayseri Kültür ve Tabiat Varlıklarını Koruma Kurulu Genel Müdürlüğü'nün 20.02.1991 tarih ve 806 sayılı yazısına göre; Seyyid Burhanettin Mezarlı̆̆ı'nın 2863 ve 3386 sayılı yasalar kapsamına giren kültür varlığı olması nedeniyle alan tescillenmiştir (Anonim, 1991).

\subsection{Metot}

Çalışma yöntemi veri toplama, analiz ve değerlendirme aşamalarından oluşmaktadır.

- İlk olarak ziyaretçilerin profili, kullanım amacı ve alan hakkında genel bilgi alanda yapılan gözlem ve ikili görüşmeler ile tespit edilmiştir.

- Daha sonra yapılan literatür taraması ve elde edilen veriler doğrultusunda mezarlığın kentsel doku içindeki konumu, alanın kentsel açık-yeşil alan sistemi içerisindeki yeri ve mevcut kullanımına yönelik bütünleşik bir değerlendirme gerçekleştirilmiştir.

- Son olarak mezarlık alanının kente ve kentsel yaşama kazandırdığı olumlu değerleri değerlendirmek amacıyla MEA (2005) tarafindan belirlenen ve ekosistem servislerinin sinıflandırmasında kullanılan parametreler temelinde bir çizelge oluşturulmuştur. Bu çizelge yardımı ile çalışma alanının sağladığı kültürel ve düzenleyici ekosistem servisleri gözleme dayalı incelenmiştir. Çalışmanın gözleme dayalı yapılmasındaki amaç, gözlemin kullanıcıların yaptıkları yada yapmadıklarını değil gerçek kullanımı ortaya çıkarmasıdır (Evensen et al., 2017). Daha sonrasında alanın kentsel açık-yeşil alan sistemleri içinde sürdürülebilirliğinin sağlanmasına yönelik öneriler getirilmiş̧ir.

\section{Bulgular ve Tartışma}

\section{1. Çalışma alanının mevcut kullanımı ve kentsel açık-yeşil alan sistemi içindeki yeri}

Selçuklu kenti olarak tanımlanan Kayseri'de bu döneme ait birçok mezarlık bulunmaktadır. 1882 yılında Jean S. Euthychides'in çizdiği Kayseri kent haritasına göre kent merkezine erişimi sağlayan üç ana aks bulunmaktadır. $\mathrm{Bu}$ üç ana aks üzerinde kente giriş kapıları olarak nitelendirilebilecek şekilde kurgulanmış Çipil, Hacı Kılıç ve Seyyid Burhaneddin Mezarlığı olmak üzere üç büyük mezarlık bulunmaktadır (Çalışır Hovardaoğlu, 2009) (Şekil 7). 


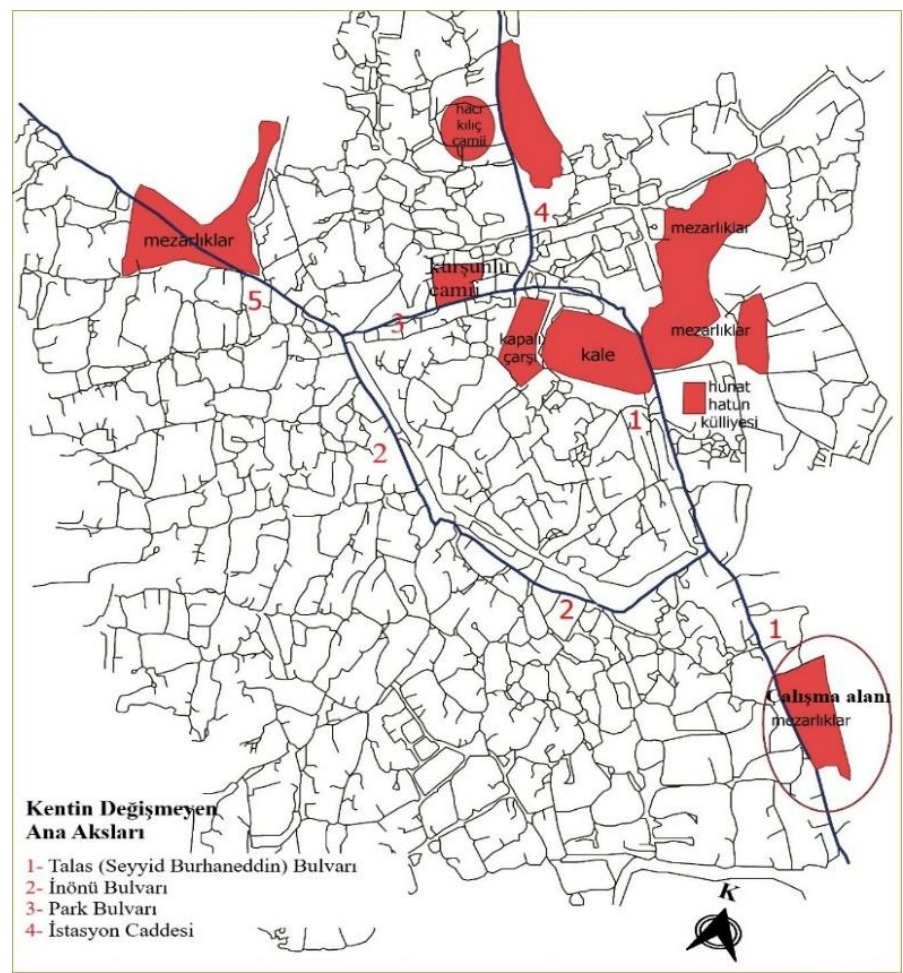

Şekil 7. Jean S. Euthychides tarafından çizilen ve kentteki mezarlıkların tamamını gösteren imar planı, 1882 ( Arın Samancı, 2019'dan faydalanılarak yeniden çizilmiştir)

Kentin gelişimi ile birlikte kaldırılan bu mezarlıklardan tarihi Seyyid Burhaneddin Mezarlığı kentin güneydoğusunda yer almaktadır. Kentin çevresindeki surların dışında kalan mezarlık günümüzde kentleşme ile birlikte tarihi kent merkezi içinde kalmıştır. Alan, yakın çevresinde bulunan tescillenmiş çok sayıda sivil mimari yapılar (tarihi konutlar) ve dini-kültürel yapılar (camii, kümbet, türbe, medrese, kale ve surları) ile birlikte tarihi kent merkezini şekillendiren yapılardan biridir (Şekil 8).

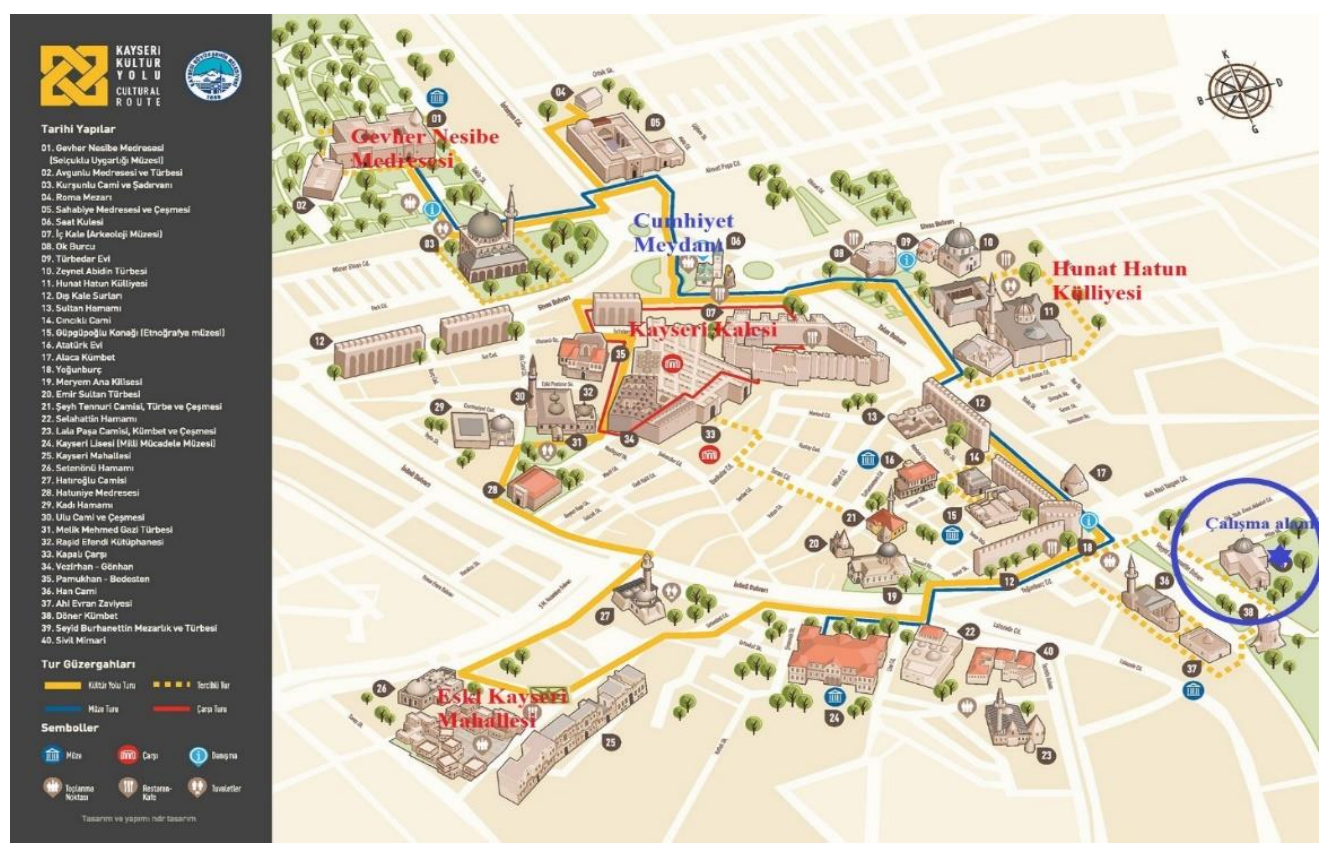

Şekil 8. Tarihi kent merkezini oluşturan ve çalışma alanı yakın çevresinde bulunan tarihi yapılar (Kayseri Büyük Şehir Belediyesi, 2020).

Ağaçlara bez bağlamak, evliya ve türbeleri ziyaret etmek ve adak adamak Türklerin İslamiyet öncesi dini inançlarından kalma bir anlayıştır (Özarslan, 2009). Bu bağlamda çalışma alanı yıl içerisinde dini günlerde, 
ramazan ayı içerisinde, özellikle evlenen çiftler, sünnet olan çocuklar, sınava girecek gençler vb. kullanıcılar tarafından sıklıkla ziyaret edilmektedir. Alan Kayseri kenti için dini ve kutsal anlamda kültürel değer barındıran bir kültürel peyzaj alanı olmakla birlikte kent içinde aktif yeşil alan olarak kullanıma sunulan tek mezarlık alanını oluşturmaktadır. Tarihi kent merkezine (Cumhuriyet Meydanı) $1 \mathrm{~km}$, kenti içi ulaşımı sağlayan otobüs seferlerinin son durağına ise 400m uzaklıktadır. Bu bağlamda alan kent içerisinde ulaşılabilirliği yüksek bir konuma sahip ve tüm kentliye hizmet eden kentin önemli açık-yeşil alanlarından biridir. Alan çevresinde özel hastaneler, konutlar, şehir kütüphanesi, kültür merkezi, kamu kurumları, iş merkezleri, şehitlik ve okullar bulunmaktadır. 2003 ve 2007 yıllarında yapılan çevre düzenlemesi ile alan girişinde bir otopark (60 araçlık), abdesthane, çay bahçesi ve tarihi Kalemkırdı Camii'ne ait bir namazgâh kurgulanmıştır. Alanın güneyindeki girişinde bulunan Seyyid Burhaneddin Camii'ne de ait bir namazgâh ve otobüs durakları bulunmaktadır. Alana Seyyid Burhaneddin (kuzey) ve Hacı Ahmed Yesevi Bulvarlarından (güney) birer ana giriş ile Nuh Mehmet Baldöktü sokağından birçok yan giriş verilmiştir (Şekil 19).

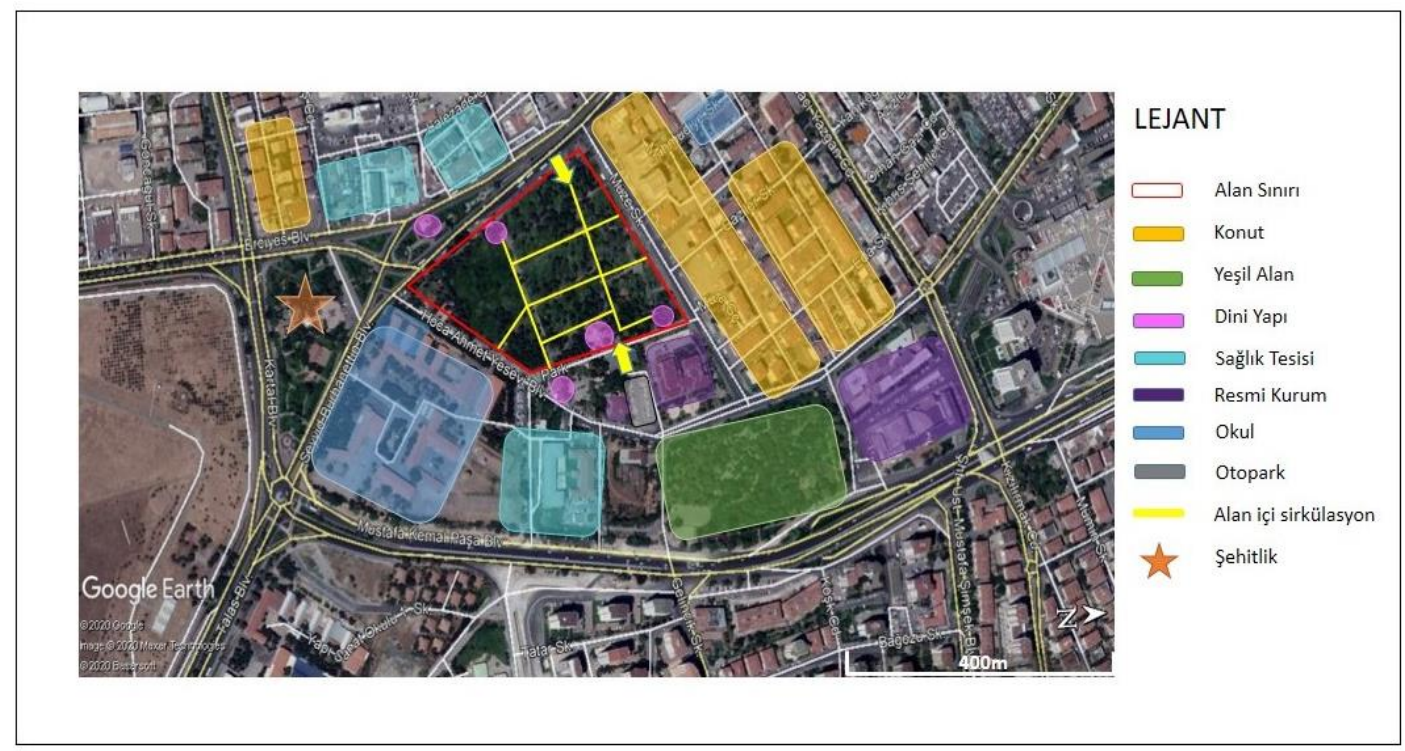

Şekil 9. Çalışma alanı ve yakın çevre alan kullanımları (Google Earth)

Alan içerisinde Mevlana'nın hocası Seyyid Burhaneddin Hz. gibi önemli bir velinin türbesini barındırması sebebiyle de dini ve manevi anlamada önemli bir ziyaretgâhtır. Dini ve kutsal anlamda dokunulmazlığı olan alan yoğun kent yaşamından ve trafiğinden uzak sakinliği ile dikkat çekmekte olup kent bütünü içinde açı-yeşil alan sistemlerinin önemli bir parçasını oluşturmaktadır. Artan kentleşme ile azalan açık-yeşil alan sitemleri içerisinde kutsallıkları ile dokunulmaz alanlar olan mezarlıklar bu anlamda kalıcı açık-yeşil alan olma anlamında garanti mekânlardır. 68 ha alan büyüklüğüne sahip tarihi mezarlığın birincil ana girişi kuzeyden olup girişi doğrudan türbe karşılamaktadır. Geniş sert zemin ve oturma elemanları ile kurgulanan bu alan mezarlığın en yoğun kullanılan bölgesini oluşturmaktadır (Şekil 10). Alan genelinde oturma elemanları bulunmamaktadır. Ancak yan ve ana girişlerde duvar üstü oluşturulan sekiler ile kullanıcılara anlık oturma ve dinlenme olanağı sunulmuştur (Şekil 11). Kent bütününde bölge parkının bulunmadığı düşünüldüğünde alan hem kent sakinlerinin hem de bulunduğu mahalle sakinlerinin pasif rekreasyon gereksinimlerini karşılamaktadır.

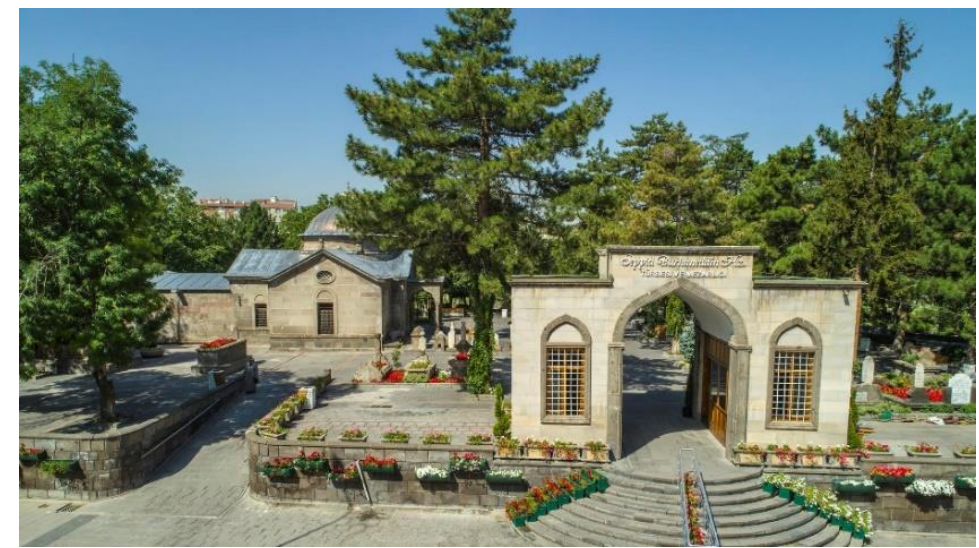

Şekil 11. Mezarlık kuzey girişi ve türbe çevresi (Anonim, 2020h) 

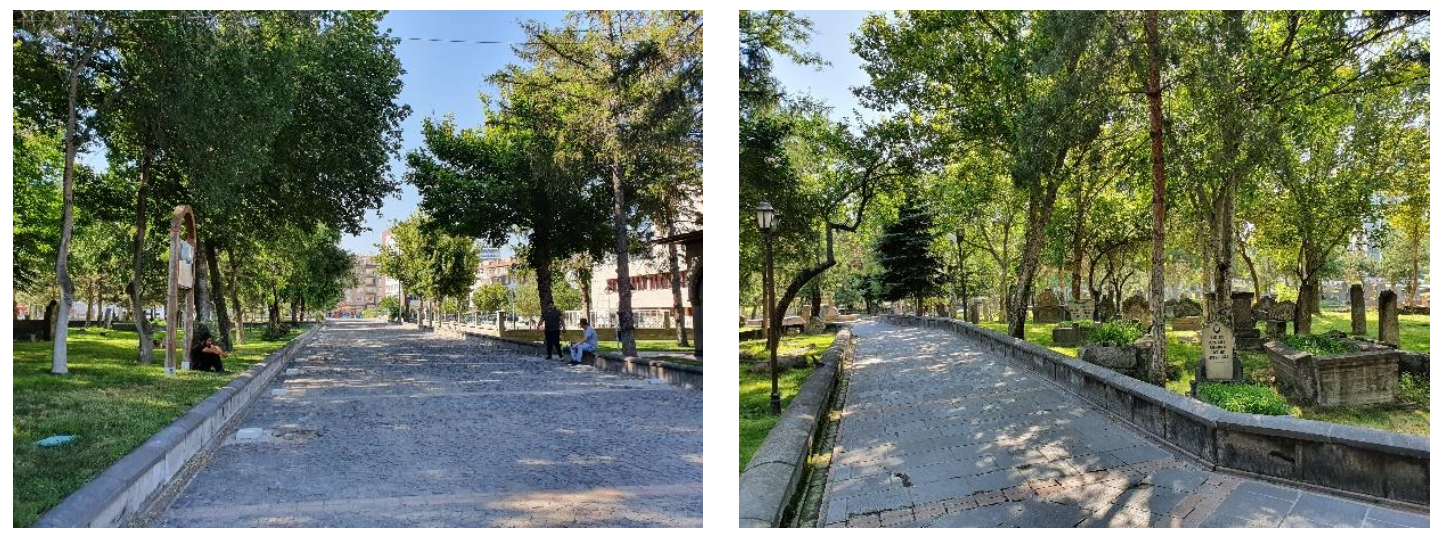

Şekil 11. Ana ve tali giriş yolların oluşturulmuş duvar üstü oturma sekileri

Mezarlıkta ağırlıklı olarak Acer negundo (Dişbudak yapraklı akçaağaç), Ailanthus altissima (Kokar ağaç), Buxus sempervirens (Adi şimşir), Catalpa bignonoides (Katalpa), Cedrus libani (Lübnan sediri), Fraxinus exelcior (Adi diş budak), Malus domestica (Elma), Morus alba (Ak dut), Picea pungens (Mavi ladin), Pinus nigra (Kara çam), Pinus nigra var. pyramidata (Ehrami Karaçam), Pinus sylvetsris (Sarı çam), Platanus orientalis (Doğu çınarı), Prunus cerasifera 'Autropurpurea' ( Süs eriği), Prunus domestica (Erik) Thuja orientalis 'Pyramidalis' (Piramit formlu doğu mazısı), Tilia cordota (Küçük yapraklı Ihlamur) ve çok sayıca mevsimlik çiçek kullanılmıştır (Şekil 12).
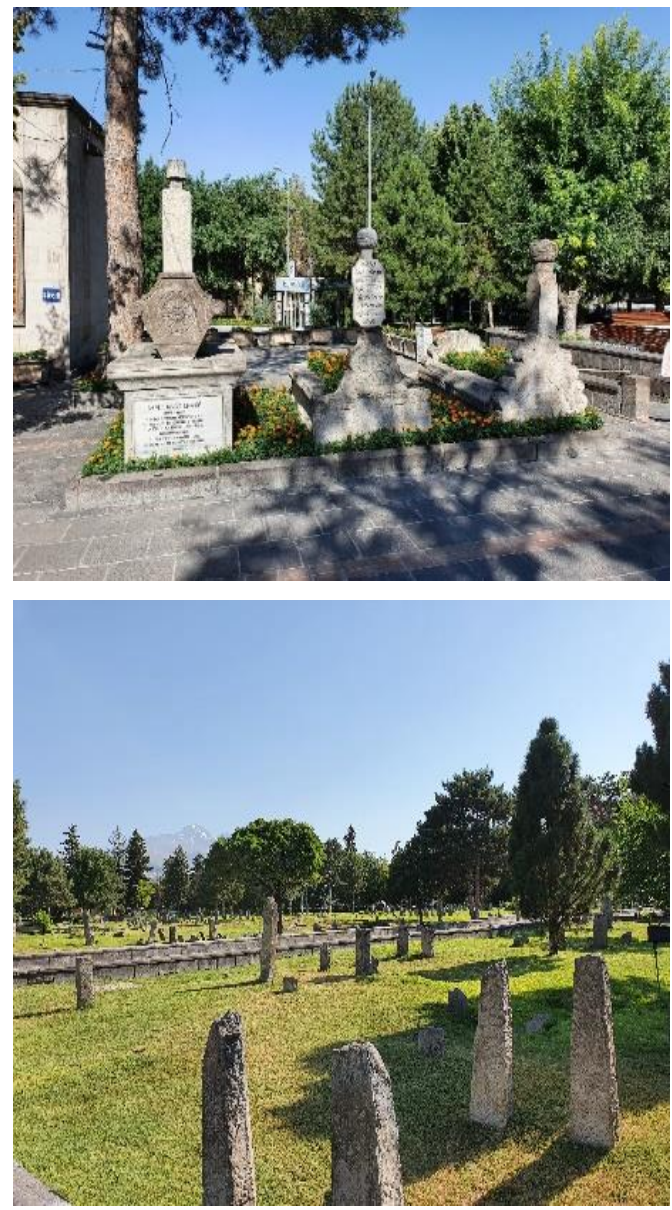
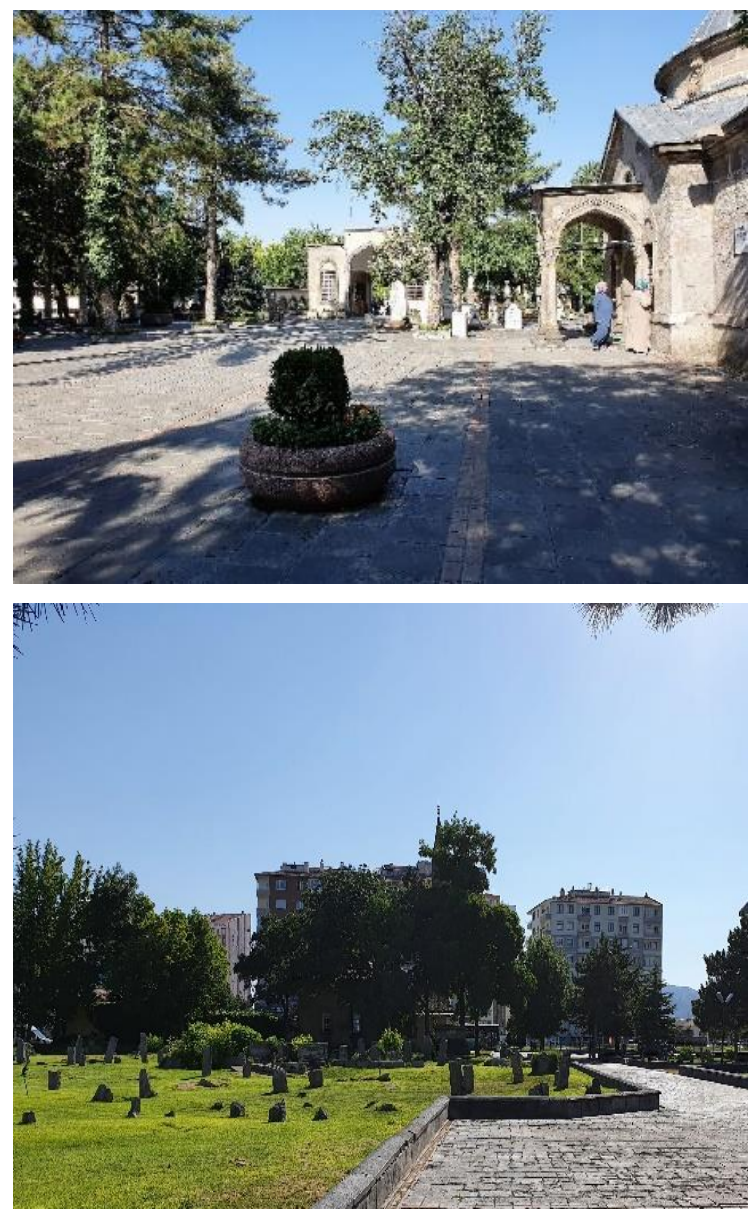

Şekil 12. Alanda yer alan bazı bitkiler 


\section{3. Çalışma alanının sunduğu ekosistem hizmetleri}

Çalışma alanında yerinde gözlem tekniğinden faydalanılarak belirlenen parametreler bakımından alanın sağladığı kültürel ve düzenleyici ekosistem hizmetleri Tablo 1'de sunulmuş̧ur.

Tablo 1. Çalışma alanının sunduğu kültürel ve düzenleyici ekosistem hizmetlerine ait bulgular

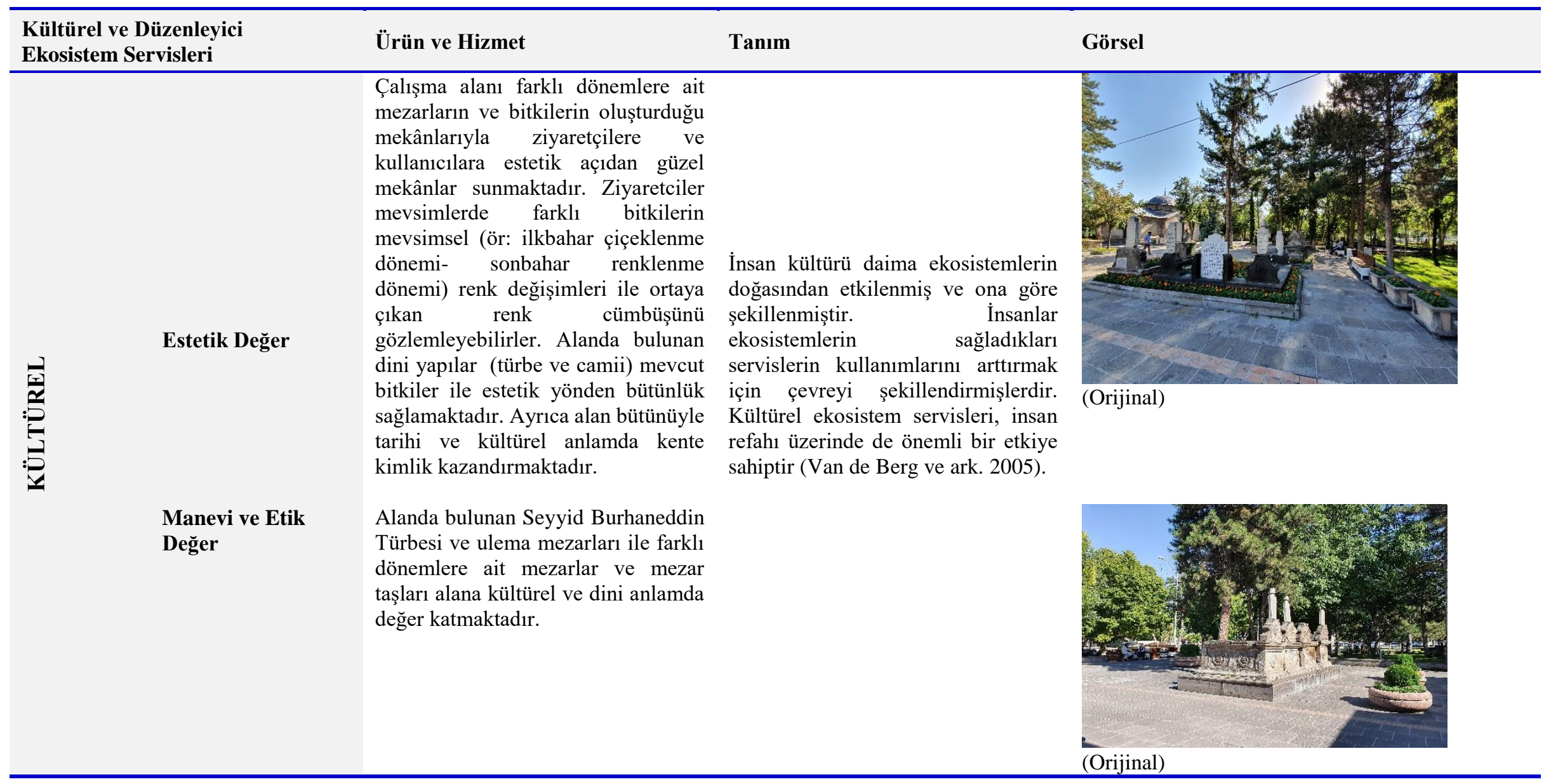


Tablo 1. Devam

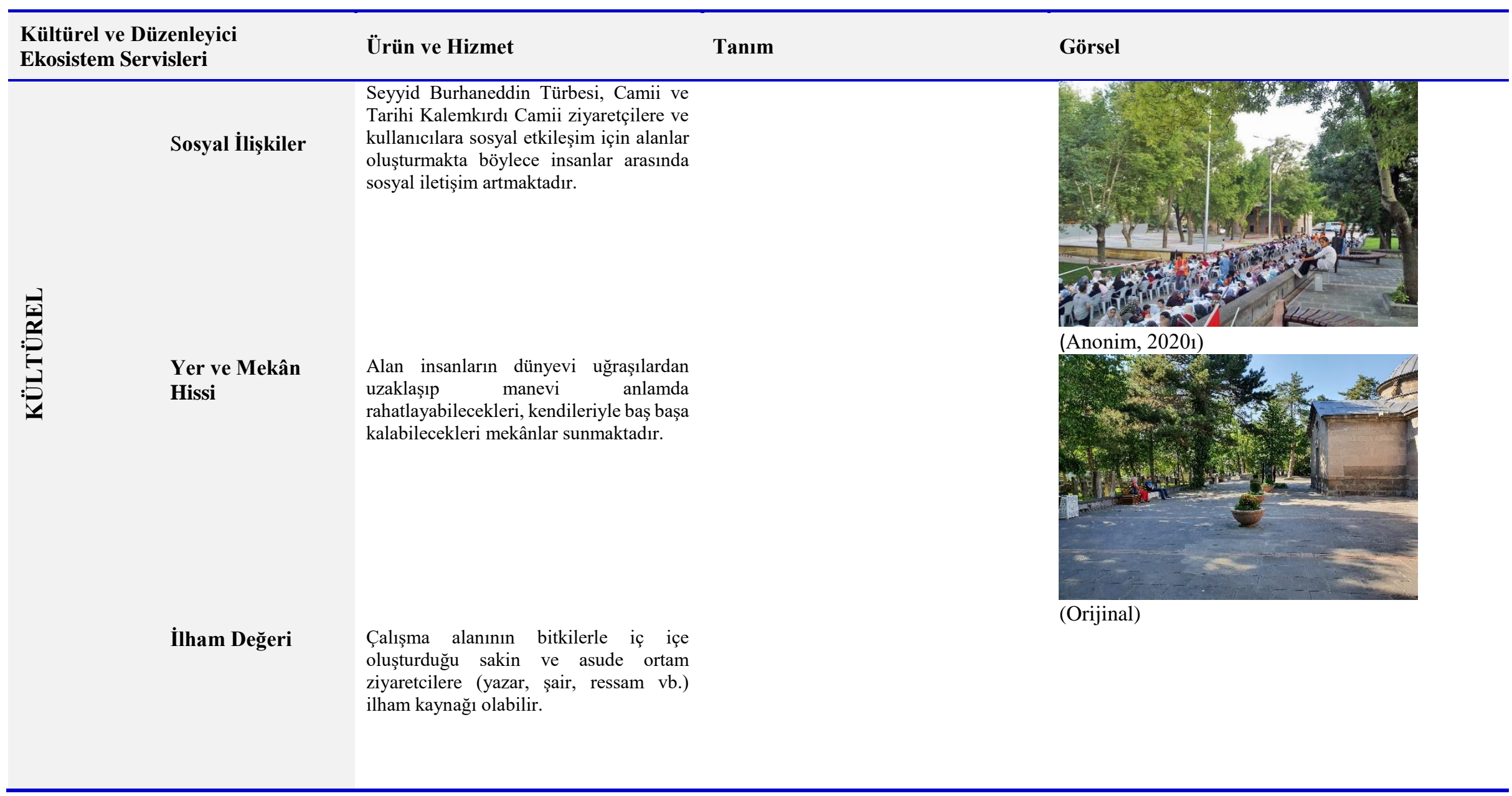


Tablo 1. Devam

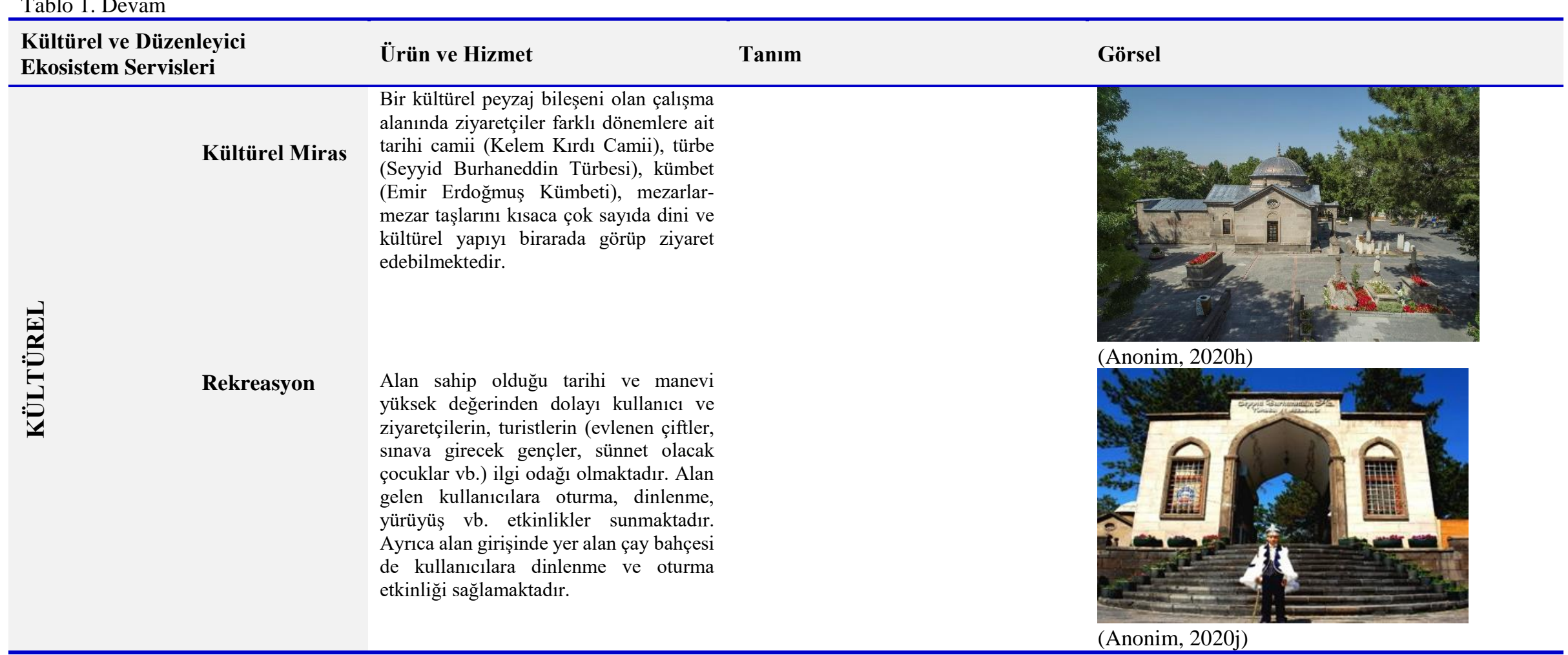


Tablo 1. Devam

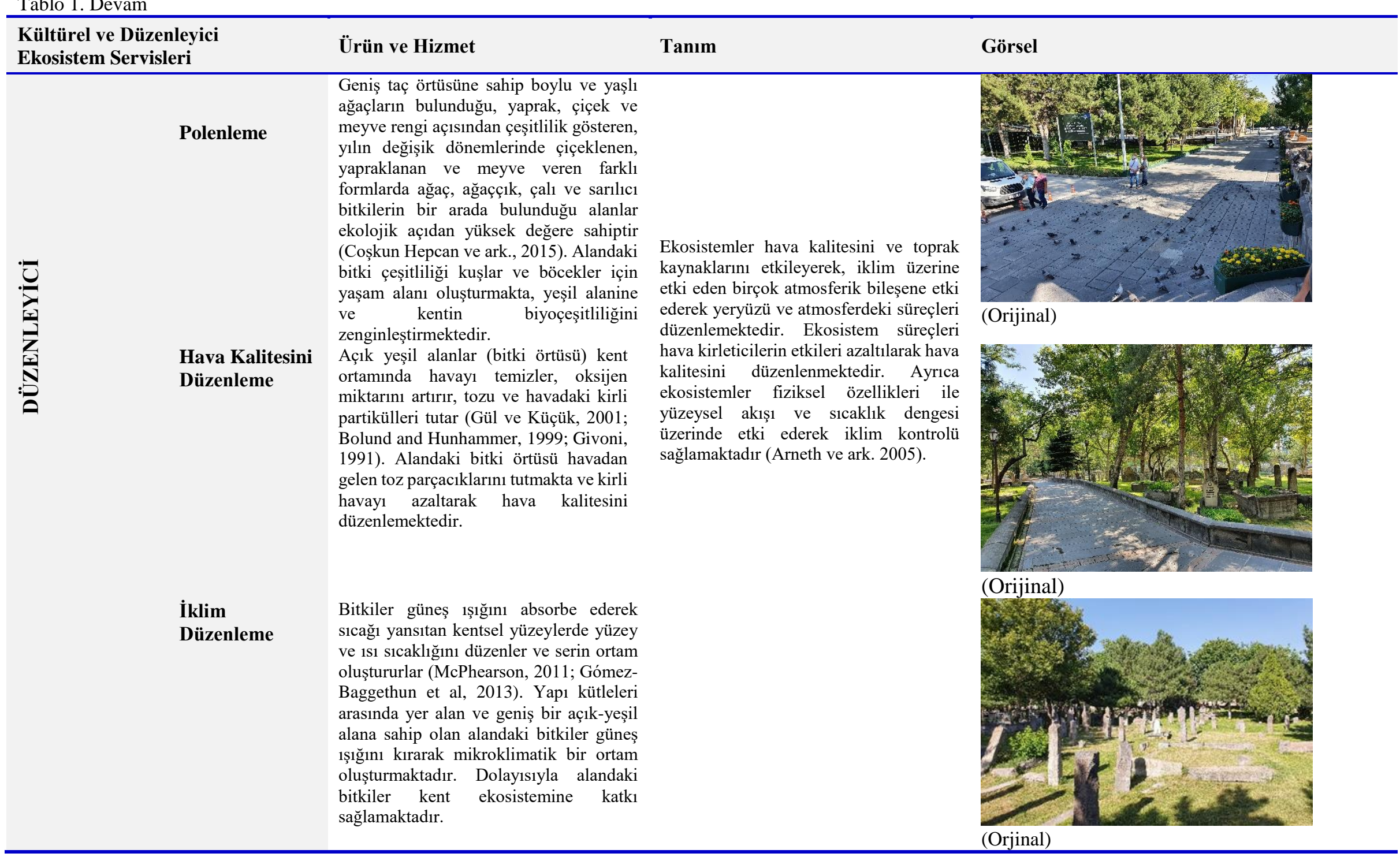




\section{Sonuç ve Öneriler}

Mezarlıklar; bir toplumun tarihinin, dini ve kültürel değerlerinin, sanat anlayışının, gelenek ve göreneklerinin yansıdığı alanlardır ( Aksoy ve Özkardaş, 2015). Mezarlıklar; mezar taşları, ağaçlar ve çitler gibi kişiye özgü yapılar ve bu yapılarla oluşturulan belirli bir mekânsal düzenlemeye dayanan, tanımlanabilir görsel özelliklere sahip kültürel peyzaj alanlarıdır (Francaviglia, 1971). Dolayısıyla mezarlıklar, kentsel doku ile doğal doku arasında ilişki kuran bir kültürel peyzaj yansımasıdır.

Anadolu kentlerinde mezarlıklar, yerleşim alanları ile iç içe kurulmuş, adeta kent parkı niteliğinde alanlar olmuşlar ve yaşayan yeşil dokular olarak kentin yapısında önemli rol oynamışlarıdır (Karaoğlu, 2007). Dolayısıyla mezarlıklar geçmişte günümüz parklarının fonksiyonlarını yüklenmiştir (Özkardaş, 2010). Günümüzde ise toplumdan uzak ve izole biçimde görevini yerine getirmektedir (Özhancı ve Aklıbaşında, 2017). Geçmişte kente giriş kapıları olarak nitelendirilebilecek üç ana aks üzerinden birinde yer alan ve üç büyük mezarlıktan biri olan Seyyid Burhaneddin Mezarlığı bugün kent içinde konutlar arasında kalmış kitlesel açıkyeşil alana sahip bir mezarlıktır.

Günümüzde yoğun yapılaşma arasında kalmış kutsal ve dokunulmaz olan mezarlıklar kentsel doku içerisinde sahip oldukları yeşil alan açısından açık-yeşil alanların önemli bir bileşenini oluşturmaktadır. Hemen hemen tüm mezarlıklar sahip oldukları yoğun bitki örtüsüyle işlevsel yeşil alanların arttırılamadığı hatta oransal olarak azaldığı kentlerde önemleri giderek artan açık-yeşil alanlardır (Karaoğlu, 2007). Kayseri kent merkezinde uygun boşlukların bulunmaması ve ulaşım şartlarından ötürü yeni yeşil alanların oluşturulması oldukça zordur. Kayseri kenti imar planına göre tarihi kent merkezi genelinde bulunan tarihi yapı çevrelerinde $865.524 \mathrm{~m}^{2}$ alan açık-yeşil alan olarak öngörülmüş̧ür (Erdoğan ve Atabeyoğlu, 2016). Bu bağlamda yaklaşık 6 ha alana sahip mezarlık, kent merkezinde bulunan ve alansal olarak en büyük ikinci açık-yeşil alanı oluşturmaktadır. Dolayısıyla kent içerisinde kentsel açık-yeşil alan sistemlerinin bir parçası olarak etkin kullanılan tarihi mezarlığın korunması ve geliştirilmesi gerekmektedir.

Kent içinde bulunan mezarlıkların, farklı kullanım alanları arasında tampon görevi olması, kent iklimini düzenlemesi, kent içindeki fauna için ayrı bir yaşam alanı oluşturması, kentin doğal bitki örtüsünü koruması, hava kirliliğini azaltması (Karaoğlu, 2007) gibi ekolojik ve şehirdekilerin psikososyal gelişiminde etkin rol alması gibi birçok kültürel ve rekreasyonel fonksiyonları bulunmaktadır (Öksüz, 2000; Özkan vd, 1996). Gelişmiş ülkeler mezarlıkları bu anlamda yeniden düzenlemeye gitmiş ve asıl işlevlerine ek olarak pasif ve aktif rekreasyon olanakları sunan açık-yeşil alanlara dönüştürmüşlerdir. Bu bağlamda çalışma alanı özgün değerleri korunarak bakımlı yeşil alanları ile kullanıcıların oturmasına ve dinlenmesine olanak tanıyan bir açık-yeşil alana dönüştürülmüştür. Ayrıca alan farklı kullanıcı ve yaş gruplarına hitap etmekte, içinde bulunan farklı dönemlere ait tarihi mezarları ile birlikte kentin önemli nirengi noktalarından birini oluşturmaktadır.

Sağıroğlu Arslan (2018) eski mezarlık alanının Ali Cafer Kümbeti ile başlayan, Seyyid Burhaneddin Mezarlığı ile devam eden, Hava Şehitliği’ni de içine alarak, Döner Kümbet ve Emir Ali Kümbeti ile Kartal Bölgesi’nde sonlanan önemli bir mezarlık bölgesi olduğunu belirtmiştir. Buradan yola çıkarak Gültepe Parkı ile başlayan ve Seyyid Burhaneddin Mezarlığı ile devam eden, Kayseri Arkeoloji Müzesini, Kent Kütüphanesini, Hava Şehitliği'ni de içine alarak, Döner Kümbet ve Emir Ali Kümbeti ile Kartal Bölgesi'nde sonlanan alan birbirine bağlı yeşil alanlar ağı (yeşil kuşak) olarak kurgulanabilir. Böylece belirlenen alan fiziksel, kültürel ve sosyal aktivitelere olanak sağlayacak şekilde planlanarak kente yaklaşık 190 ha'lık bir açık-yeşil alan kazandırılabilir (Şekil 13).

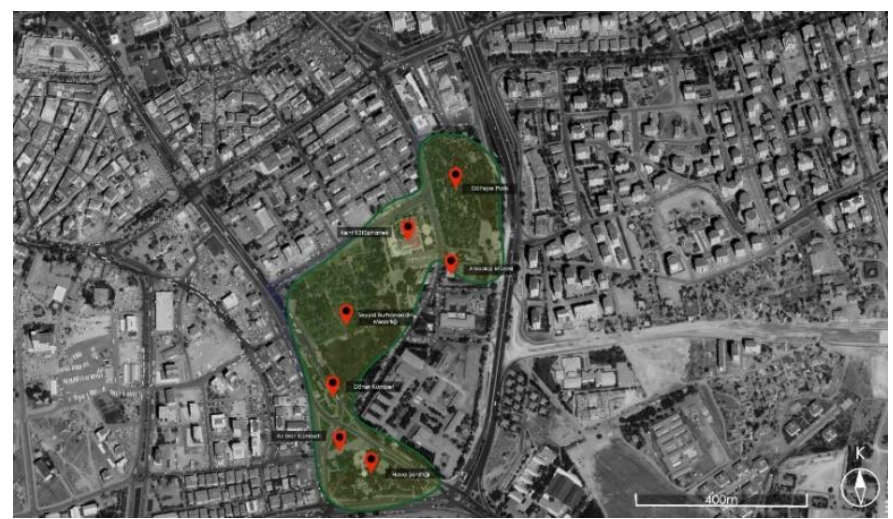

Şekil 13. Oluşturulabileceği öngörülen yeşil kuşak (Google Earth) 
Açık-yeşil alanların rekreasyonel, estetik ve kültürel anlamda sağladıkları yararlar, kentlere sundukları en önemli ekosistem hizmetleridir (Bolund and Hunhammer, 1999; Nesbitta et. al., 2017). Dolayısıyla açık-yeşil alanlar kimlikli ve sürdürülebilir kentlerin oluşturulmasında önemli mihenk taşlarıdır. Kültürel peyzajın yalnızca bir elemanı olan mezarlıklar (Francaviglia, 1971) farklı kültürler ve gelenekler hakkında görsel ve mekânsal olarak bilgi vererek önemli kültürel ekosistem hizmetleri sunarlar. Kentleşme baskısına karşın sahip oldukları yeşil dokusu (bitki örtüsü) ile mezarlıklar mutlak korunmalıdır. Çalışma alanı düzenleyici servisler bakımından hava kalitesini düzenleme, iklimi düzenleme ve polenleme gibi özelliklerinin, kültürel servisler bakımından ise kültürel miras, ilham değeri, rekreasyon, sosyal ilişkiler, yer ve mekan hissi özelliklerinin sağlandığı söylenebilir. Ancak alan genelinde bitki türü çeşitliliğinin az olması ve plantasyonun belirli tasarım ilkeleri çerçevesinde yapılmamış olması sebebiyle mevcut bitkilerin sağladığı ekosistem hizmetlerinin yeterli düzeyde olduğu söylenemez. Dolayısıyla alan genelinde bitkisel anlamda yapılacak revize çalışmaları ile bitkilerin sağladıkları ekosistem hizmetlerinden elde edilen faydaların sürdürülebilir olması sağlanabilir. Çünkü ekosistem hizmetleri çevresel kalitenin, yaşam kalitesinin ve sürdürülebilir kent yönetiminin gelişimine katkıda bulunmaktadır (Jim and Chen, 2009).

Sonuç olarak nitelikli açık-yeşil alanlara sahip mezarlıkların kentsel peyzaja aktif yeşil alan olarak kazandırılması ile sağladıkları ekosistem hizmetleri desteklenebilir ve nitelikli sürdürülebilir kentsel açık-yeşil alan sistemlerinin planlanması sağlanabilir. Bu bağlamda kentlinin açık-yeşil alanlara erişebilmelerini ve sundukları birçok ekosistem hizmetlerinden yararlanabilmelerini sağlamak için bu alanların uygun şekilde planlanması, tasarlanması ve yönetilmesi önemlidir. Bu çalışmanın ekosistem hizmetleri ve mezarlıklar arasındaki bağlantının bütüncül bir yaklaşımla, ele alınan bir çalışma olması sebebiyle gelecekteki çalışmalara yön göstereceği olacağı düşünülmektedir.

\section{Kaynaklar}

1. Aksoy, Y. ve Özkardaş, V. (2015). Karacaahmet Mezarlı̆̆ı Peyzaj Tasarımı Ve Bakım Çalışmaları Açısından İncelenmesi. İstanbul Aydın Üniversitesi Dergisi Yıl 3, Sayı 12, Sayfa (83-102).

2. Aktan N. G., (1999). Fiziksel planlama yönünden İzmir ve Frankfurt kent mezarlıklarının $\quad$ karşılaştırılması, $\quad$ Yüksek $\quad$ Lisans $\quad$ Tezi, $\quad$ Ege Üniversitesi Fen Bilimleri Enstitüsü, İzmir.

3. Akurgal, E., (1990). " Anadolu Uygarlıkları", Net Turistik Yayınlar, Sanayi ve Ticaret A.Ş., Asır Matbaacilik, İstanbul

4. Albayrak, İ., (2012). Ekosistem Servislerine Dayalı Havza Yönetim Modelinin İstanbul Ömerli Havzası Örneğinde Uygulanabilirliği. Doktora Tezi. İstanbul Teknik Üniversitesi, Fen Bilimleri Enstitüsü, İstanbul, $198 \mathrm{~s}$.

5. Anonim (1991). Kayseri Kültür ve Tabiat Varlıklarını Koruma Kurulu Raporu, 20 Şubat Kayseri

6. Anonim (2005). The service of nature, living beyond our means: natural assets and human well-being. Millennium Ecosystem Assessment, Island Press, Washington, 28, DC.

7. Anonim (2020a). https://www.webtekno.com/keops-piramidi-nde-yolcu-ucagi-buyuklugunde-odakesfedildi-h36048.html

8. Anonim (2020b). https://bilgihanem.com/tac-mahal-hakkinda-bilgiler/

9. Anonim (2020c). https://www.tripadvisor.com.tr/ShowUserReviews-g312741-d311760-r275573618Cemiterio_de_Recoleta-Buenos_Aires_Capital_Federal_District.html

10. Anonim (2020d). http://www.turkbilimi.com/tuva-arzhan-buluntulari-arjaan-2-kurgani-mo-8-yuzyil/

11. Anonim (2020e). http://www.serenti.org/turklerin-tarihe-biraktigi-iz-balbal/

12. Anonim (2020f). http://wowturkey.com/t.php? $\mathrm{p}=/ \operatorname{tr} 139 / \mathrm{hbbilik}$ donerkumbet1.jpg

13. Anonim (2020 g). http://wowturkey.com/t.php?p=/tr618/onurnazliaka_IMG_6494a.jpg

14. Anonim (2020h). http://www.havadankayseri.net/portfolio/seyyid-burhaneddin-hz-turbesi/

15. Anonim (20201).

http://wowturkey.com/t.php?p=/tr475/Hasan_Yuksel_Seyyid_Burhaneddinde_Ramazan_Aksam.jpg

16. Anonim, (2020j).

http://wowturkey.com/t.php?p=/tr321/SABRI_KAVUNCU_seydiburhanettin_turbesi.jpg

17. Arın Samancı, K.M., (2019). Kayseri Meydanının Cumhuriyet Dönemi Modernizm Yaklaşımı Bağlamında Değişimi: Eski Hükümet Konağı Örneği, Yüksek Lisans Tezi, İstanbul Teknik Üniversitesi, Fen Bilimleri Enstitüsü, Mimarlık Anabilim Dalı, İstanbul.

18. Arneth, A., Barratt, D., Cassman, K., Christensen, T., Cornell, S., Foley, J., Ganzeveld, L., Thomas, H., Houweling, S., Scholze, M., Joos, F., Kohfeld, K., Manizza, M., Ojima, D., Prentice, I.C., Schaaf, C., Smith, B., Tegen, I., Thonicke, K., Warwick, N., (2005). Climate And Air Quality İn Hassan, R., 
Scholes, R. Ve Ash, N., Eds, Ecosystems and Human Well-being: Current State and Trends Volume 1, 357 - 384, Island Press, Washington DC, London

19. Başkan, S., (1996). Karaman oğulları Dönemi Konya Mezar Taşları. Ankara, Kültür ve Turizm Bakanlığı Yayınları.

20. Bekiroğlu, M.S., (1990). İstanbul'daki Mezarlıkların Peyzaj Açısından İrdelenmesi. Yüksek Lisans Tezi. Yıldız Teknik Üniversitesi Fen Bilimleri Enstitüsü

21. Bulut, Z., Kılıçaslan, Ç., Deniz, B. ve B. Kara, (2010). Kentsel Ekosistemlerde Sürdürülebilir ve AçıkYeşil Alanlar, III. Ulusal Karadeniz Ormancılık Kongresi, Cilt:IV, S: 1484-1493, 20-22 Mayıs 2010, Artvin.

22. Bolund, P., Hunhammar, S., (1999). "Ecosystem services in urban areas”, Ecological Economics, vol. 29, pp. 293-301.

23. Bowler, D.E., Buyung-Ali, L., Knight, T.M., Pullin, A.S., (20109. "Urban Greening to Cool Towns and Cities: A Systematic Review of the Empirical Evidence”, Landscape and Urban Planning, 97: 147-155

24. Coşkun Hepcan, Ç., Özeren Alkan, M. veÖzkan, M.B. (2015). Ege Üniversitesi Rektörlük Bahçesi Bitki Atlası. Ege Üniversitesi Rektörlük Yayınları, 18.

25. Çalışır Hovardaoğlu, S., (20099. Tarihi Süreklilikte Kentsel Katmanlaşmanın Belgelenmesi Bağlamında Kayseri Kent Merkezi, Doktora Tezi, İstanbul Teknik Üniversitesi, Fen Bilimleri Enstitüsü, İstanbul.

26. Çalışkan, N., (19959. Kuruluşundan Günümüze Kayseri Belediyesi, Kayseri, s. 40, 41.

27. Clayden, A., Green, T., Hockey, J., Powell, M., (2018). Cutting the lawn-natural burial and its contribution to the delivery of ecosystem services in urban cemeteries. Urban Forestry and Urban Greening, 33, 99-106

28. Daneshvari, A., (1986). "Medieval Tomb Towers of Iran”, (Mazda Publishers,Lexington)

29. Depietri, Y., Renaud, F.G., Kallis, G., (2012). "Heat Waves and Floods in Urban Areas: A PolicyOriented Review of Ecosystem Services", Sustainability Science, 7(1): 95-107

30. Eminağaoğlu, Z.ve Yavuz, A., (2010). Kentsel Yeşil Alanların Planlanması ve Tasarımını Etkileyen Faktörler: Artvin İli Örneği, III. Ulusal Karadeniz Ormanc1lık Kongresi, 20-22 Mayıs, Cilt: IV, s: 153661547, Artvin Çoruh Üniversitesi, Artvin

31. Erdoğan, A., Atabeyoğlu, Ö. (2016). Tarihi yapıların kentsel dokuya etkisi: Kayseri kent merkezi örneği, Turkish Journal Of Forestry, 17(1), 83-92

32. European Environment Agency (EEA), (1995). Europe's Environment: The Dobris Assessment. Stanners, D., Bourdeau, P. (Eds.), Copenhagen.

33. European Environment Agency (EEA), (1998). State of the European Environment. Copenhagen

34. Evensen, K., Nordh, H., Skaar, M., (2017). Everyday use of urban cemeteries: a Norwegian case study. Landsc. Urban Plan. 159, 76-84

35. Eyice, S., (1996). Mezarlıklar ve hazireler, İslam Dünyasında Mezarlıklar ve Defin Gelenekleri Cilt:1. Ankara: Türk Tarih Kurumu Basımevi. ss: 122-134.

36. Francaviglia, R.V., (1971). The Cemetery As An Evolving Cultural Landscape, Annals of the Association of American Geographers, Vol. 61, No. 3, pp. 501-509

37. Girardet, H., (1992). The GAIA Atlas of Cities: New Directions for Sustainable Urban Living. Anchor Books, New York

38. Givoni, B., (1991). Impact of planted areas on urban environmental quality: a review. Atmospheric Environment. Part B. Urban Atmosphere, vol. 25, pp.289-299

39. Gómez-Baggethun, E., Gren, A., Barton, D. N., Langemeyer, J., McPhearson, T., O'Farrell, P., Andersson, E., Hamstead, Z., Kremer, P., (2013). Urban Ecosystem Services, T. Elmqvist et al. (eds.), Urbanization, Biodiversity and Ecosystem Services: Challenges and Opportunities: A Global Assessment, 175-251

40. Gönen, G., (1992) Mezarlıklar, Peyzaj Mimarlığı Dergisi, 3:34-35

41. Güçlü, K., Yılmaz S., Yılmaz H., (1996). Kentsel Yeşil Doku İçinde Mezarlıkların Yeri, Önemi ve Erzurum Örneği. Atatürk Üniversitesi Ziraat Fakültesi Dergisi 27 (1), sayfa 1-12, Erzurum

42. Gül, A., Küçük, V., (2001). Kentsel Açık-Yeşil Alanlar Ve Isparta Kenti Örneğinde İrdelenmesi, Süleyman Demirel Üniversitesi, Orman Fakültesi Dergisi, sayı:2, s:27-48, Isparta.

43. Güneş, F., (1995). Türklerde Defin Merasimi. Yüksek Lisans Tezi. Kayseri: Erciyes Üniversitesi, Sosyal Bilimler Enstitüsü.

44. Hüsrevoğlu, M., (2017). Mevlânâ'nın Üstadı Seyyid Burhanedin Hazretleri, Kayseri

45. İmamoğlu, V., (1997). “20. Yüzyılın ilk yarısında Kayseri Kent: Fiziki Çevre ve Yaşam”, I. Kayseri ve Yöresi Tarih Sempozyumu Bildirileri, Kayseri, s. 120.

46. Jim, C.Y., Chen, W.Y., (2009). Ecosystem services and valuation of urban forests in China. Cities 26 (4), 187-194.

47. Jo, H.K., (2013). "Impacts of Urban Green Space on Offsetting Carbon Emissions for Middle Korean", Journal of Environmental Management, 64: 115-126, 2002. 
48. Karaoğlu, D., (2007). Kent Mezarlıklarının Yeşil Doku İçerisindeki Önemi Ve Ziyaretçi Memnuniyetinin belirlenmesi - Karacaahmet Mezarlığı Örneği. İstanbul Teknik Üniversitesi Fen Bilimleri Enstitüsü, Yüksek lisans Tezi, 121s, İstanbul.

49. Karaşah, B., (2018). Determınatıon Of Cultural Ecosystem Servıces Provıded By Botanıc Gardens 'Case Of Batumı Botanıcal Garden, Georgia, Researches On Science And Art In 21st Century Turkey, Volume:2, p: 2033

50. Kattwinkel, M., Biedermann, R., Kleyer, M., (2011). "Temporary Conservation for Urban Biodiversity”, Biological Conservation, 144(9): 2335-2343

51. Kayseri Büyük Şehir Belediyesi, (2020). Kültür Yolu Envanter Haritası.

52. Korkut, A., Kiper, T., Üstün Topal, T., (2017). Kentsel Peyzaj Tasarımda Ekolojik Yaklaşımlar. Artium Dergisi, Cilt:5, No:1, s:14-26

53. La Rosa, D., (2014). "Accessibility to Greenspaces: GIS Based Indicators for Sustainable Planning in a Dense Urban Context”, Ecological Indicators, 42: 122-134

54. Lynch, K., (1985). Good City Form Book. The Mit Pres.

55. Manes, F., Incerti, G., Salvatori, E., Vitale, M., Ricotta, C., Constanza, R., (2012). "Urban Ecosystem Services: Tree Diversity and Stability of Tropospheric Ozone Removal” Ecological Applications, 22(1): 349-369

56. McPhearson, T., (2011). Toward a sustainable New York City: Greening through urban forest restoration. In E. Slavin (Ed.), Sustainability in America's Cities: Creating the Green Metropolis (pp. 181-204). Island Press: Washington, DC

57. MEA, (2005).Ecosystems and Human Well-Being: Synthesis. Millennium Ecosystem Assessment, Island Press, Washington, DC

58. Nesbitta, L., Hotte, N., Barron, S., Cowan, J., Stephen, R.J., Sheppard, S.R.J., (2017). “The Social and Economic Value of Cultural Ecosystem Services Provided by Urban Forests in North America: A Review and Suggestions for Future Research", Urban Forestry and Urban Greening, 25: 103-111

59. Pathak, V., Tripathi, B.D., Mishra, V.K., (2011). "Evaluation of Anticipated Performance Index of Some Tree Species for Green Belt Development to Mitigate Traffic Generated Noise", Urban Forestry and Urban Greening, 10(1): 61-66

60. Qin, J., Zhou, X., Sun, C., Leng, H., Lian, Z., (2013). "Influence of Green Spaces on Environmental Satisfaction and Physiological Status of Urban Residents", Urban Forestry and Urban Greening, 12: 490497

61. Rebele, F., (1994). "Urban ecology and special features of urban ecosystems,"Global Ecology and Biogeography Letter, vol. 4, pp. 173-187

62. Sağıroğlu Arslan, A., (2018). Seyyid Burhaneddin Hz. Mezarlığı, Mezarları ve Mezar Taşları Kayseri Büyükşehir Belediyesi Kültür Yayınları Sanat Dizisi, Cilt 1, No: 141

63. Sander, H.A., Zhao, C., (2015). "Urban Green and Blue: Who Values What and Where?", Land Use Policy, 42: 194-209

64. Saraçoğlu, N., (1950). Türk Mezarlarına Dair Araştırma, İ.T.Ü. Mimarlık Fakültesi, İstanbul.

65. Satoğlu, A. (1968). Mevlâna'nın Hocası Seyyid Burhaneddin, s.42-43

66. Öztan, Y., (1974). “ Hipodrom ve Golf Klubü” Peyzaj Mimarlığı Dergisi, Cilt:5, Sayı : 1 Tisa Matbaacılık Sanayi, Ankara.

67. Özarslan, E., (2007). Mezarlıkların Peyzaj Planlama ve Tasarımı Açısından İncelenmesi: İstanbul Zincirlikuyu Mezarlığı Örneği. İstanbul Teknik Üniversitesi Fen Bilimleri Enstitüsü, Yüksek Lisans Tezi, $121 \mathrm{~s}$, İstanbul.

68. Özarslan, M., (2009). Üsküdar'da Yatır ve Ziyaret Yerleri, Motif Akademi Halkbilimi Dergisi 2 (3-4), s:300-308

69. Özdemir, H.G., (2012). Değişik Açık Ve Yeşil Alanlarda Bitkisel Tasarım Yönünden Güvenilirlik Faktörünün Analizi, Yüksek Lisans Tezi, Atatürk Üniversitesi, Fen Bilimleri Enstitüsü, Erzurum, 119s.

70. Özhancı, E., ve Aklıbaşında, M., (2017). Kentsel Peyzaj İçinde Mezarlıklar ve Peyzaj Mimarlığ Açısından İncelenmesi; Nevşehir Örneği, Atatürk Üniversitesi Ziraat Fakültesi Dergisi, 48 (2), 2017, s.113124

71. Özkan, B., Küçükerbaş, E. V. Ve Kaplan, A., (1996). Açık-yeşil alan ve rekreasyon alanı olarak mezarlıkların planlama ve tasarın sorunları ile çözüm olanakları İzmir kenti örneğinde araştırılması, Ege Üniversitesi Ziraat Fakültesi Peyzaj Mimarlığı Bölümü, E.Ü. Araştırma Fonu Araştırma Raporu, Proje No: 1994/006, Bornava-İzmir.

72. Özkardaş, V., (2010). İstanbul Mezarlıklarının Peyzaj Planlama, Tasarım ve Bakım Çalışmaları Açısından İncelenmesi Karacaahmet Mezarlığı Örneği. Bahçeşehir Üniversitesi Fen Bilimleri Enstitüsü, Yüksek Lisans Tezi, 409s, İstanbul. 
73. Öksüz, K., (2000). Kent ve peyzaj planlama çerçevesinde kıyı dolgu düzenlemelerinin incelenmesi: Maltepe-Bostancı ve Samatya dolgu alanları sahil parklarının peyzaj planlama açısından irdelenmesi, Yüksek Lisans Tezi, İ.T.Ü. Fen Bilimleri Enstitüsü, İstanbul.

74. Sommer, A. L. (2003). «De Dødes Haver: Den Moderne Storbykirkegård.» Odense: Syddansk Universitetsforlag

75. Taner, T., (1988). Şehir Mezarlıkları Planlama İlkeleri, D.E.Ü. Güzel Sanatlar Fakültesi No: 0904-AR-88026, İzmir.

76. Tuncel, G., (1989). Batı Anadolu Bölgesinde cami ve tasvirli mezar taşları, Kültür Bakanlığı Yayınları. Tanitma Eserleri Dizisi. Mas matbaacilık. Ankara.

77. Tuncer, M., (1996). "Türbe Ziyaretlerinin Psiko-Sosyal Sebepleri ve Tezahürleri”, Y. Lisans Tezi, Marmara Üniversitesi, Sosyal Bilimler Enstitüsü, İstanbul

78. Uslu, A., (1997). "Tarihi Süreç İçerisinde Anadolu Mezarlıkları ve Çağdaş Bir Yaklaşımla Ankara Kenti için Örnek Bir Mezarlık Planlaması Üzerinde Bir Araştırma”, Doktora Tezi, Ankara Üniversitesi, Fen Bilimleri Enstitüsü, Ankara

79. Uslu, A., (2010). An ecological approach for the evaluation of an abandoned cemetery as a green area: The case of Ankara /Karakusunlar cemetery. African Journal of Agricultural Research, 5 (10), pp. 1043-1054

80. Van De Berg, A., Kulenthran, T., Muller, S., Pitt, D., Wascher, D., Wijesuriya, G., (2005). Cultural and Amenity Services in Hassan, R., Scholes, R. ve Ash, N., eds, Ecosystems and Human Well-being: Current State and Trends Volume 1, 457 - 473, Island Press, Washington DC, London.

81. Velarde, M.D, Fry, G., Tveit, M., (2007). "Health Effects of Viewing Landscapes - Landscape Types in Environmental Psychology", Urban Forestry and Urban Greening, 6(4): 199-212

82. Worpole, K., (2003). Last Landscapes: The Architecture of the Cemetery in the West. Garden History Vol. 31, No. 2 (Winter, 2003), pp. 229-230 (2 pages) 